\title{
Role of the hypothalamic-pituitary-thyroid axis in metabolic regulation by JNK1
}

\author{
Guadalupe Sabio, ${ }^{1,2,5}$ Julie Cavanagh-Kyros, ${ }^{1,2}$ Tamera Barrett, ${ }^{1,2}$ Dae Young Jung, ${ }^{2,3}$ Hwi Jin Ko, ${ }^{2,3}$ \\ Helena Ong, ${ }^{2}$ Caroline Morel, ${ }^{1,2}$ Alfonso Mora, ${ }^{2}$ Judith Reilly, ${ }^{2}$ Jason K. Kim, ${ }^{2,3,4}$ and Roger J. Davis ${ }^{1,2,6}$ \\ ${ }^{1}$ Howard Hughes Medical Institute, University of Massachusetts Medical School, Worcester, Massachusetts 01605, USA; \\ ${ }^{2}$ Program in Molecular Medicine, University of Massachusetts Medical School, Worcester, Massachusetts 01605, USA; \\ ${ }^{3}$ Department of Cellular and Molecular Physiology, Pennsylvania State University College of Medicine, Hershey, \\ Pennsylvania 17033, USA; ${ }^{4}$ Department of Medicine, Division of Endocrinology, Metabolism and Diabetes, University of \\ Massachusetts Medical School, Worcester, Massachusetts 01605, USA
}

The cJun N-terminal kinase 1 (JNK1) is implicated in diet-induced obesity. Indeed, germline ablation of the murine Jnk1 gene prevents diet-induced obesity. Here we demonstrate that selective deficiency of JNK1 in the murine nervous system is sufficient to suppress diet-induced obesity. The failure to increase body mass is mediated, in part, by increased energy expenditure that is associated with activation of the hypothalamicpituitary-thyroid axis. Disruption of thyroid hormone function prevents the effects of nervous system JNK1 deficiency on body mass. These data demonstrate that the hypothalamic-pituitary-thyroid axis represents an important target of metabolic signaling by JNK1.

[Keywords: JNK1; obesity; insulin resistance; thyroid hormone]

Supplemental material is available at http://www.genesdev.org.

Received October 27, 2007; revised version accepted December 4, 2009.

Human obesity represents a serious world-wide health problem. One consequence of obesity is the development of insulin resistance, hyperglycemia, and metabolic syndrome that can lead to $\beta$-cell dysfunction and type 2 diabetes (Kahn et al. 2006). It is therefore important that we gain an understanding of the physiology and pathophysiology of the development of obesity, because this knowledge represents a basis for the design of potential therapeutic interventions.

The cJun $\mathrm{N}$-terminal kinase 1 (JNK1) represents one signaling pathway that has been implicated in dietinduced obesity (Weston and Davis 2007). JNK1 is activated when mice are fed a high-fat diet (HFD) (Hirosumi et al. 2002). Moreover, $I n k 1^{-/-}$mice are protected against HFD-induced weight gain (Hirosumi et al. 2002). The mechanism that accounts for the effect of germline JNK1 deficiency to control body weight is unclear. Tissue-specific deficiency of JNK1 in fat, muscle, liver, and myeloid cells does not affect HFD-induced weight gain (Sabio et al. 2008, 2009, 2010). A different organ must therefore play a major role in the diet-induced regula-

${ }^{5}$ Present address: Departamento de Inmunología y Oncología, Centro Nacional de Biotecnología, CSIC Campus de Cantoblanco-UAM, 28049 Madrid, Spain.

${ }^{6}$ Corresponding author.

E-MAIL roger.davis@umassmed.edu; FAX (508) 856-3210.

Article published online ahead of print. Article and publication date are online at http://www.genesdev.org/cgi/doi/10.1101/gad.1878510. tion of body weight by JNK1. The brain represents a possible site of JNK1 function because the hypothalamus and pituitary gland are known to regulate metabolism, including feeding behavior, physical activity, and energy expenditure (Lenard and Berthoud 2008).

The purpose of this study was to investigate the role of JNK1 in the brain. Our approach was to examine the effect of selective ablation of the $I n k 1$ gene in the mouse nervous system. We found that HFD-fed control $\left(\mathrm{N}^{\mathrm{WT}}\right)$ mice gained substantially greater body weight than JNK1deficient $\left(\mathrm{N}^{\mathrm{KO}}\right)$ mice. The decreased weight gain by $\mathrm{N}^{\mathrm{KO}}$ mice was accounted for by decreased food intake, increased physical activity, and increased energy expenditure. These changes were associated with increased amounts of thyroid hormone in the blood and increased expression of thyroid hormone-responsive genes in target tissues. Importantly, pharmacological inhibition of thyroid hormone markedly attenuated $\mathrm{N}^{\mathrm{KO}}$ phenotypes. These data demonstrate that the hypothalamic-pituitary-thyroid axis is a major target of the JNK1 signaling pathway that regulates metabolism.

\section{Results}

To investigate the role of JNK1 in the nervous system, we created compound mutant mice (Nestin-cre $\operatorname{Ink} 1^{\text {LoxP/LoxP }}$ ) with a selective defect in the expression of JNK1. Genotype analysis of $\mathrm{N}^{\mathrm{WT}}$ and $\mathrm{N}^{\mathrm{KO}}$ mice demonstrated that the 
$\operatorname{Ink} 1^{\operatorname{Lox} P}$ allele was efficiently deleted in the nervous system of $\mathrm{N}^{\mathrm{KO}}$ mice (Fig. 1A). Thus, the Ink1 gene was ablated in all regions of the CNS of $\mathrm{N}^{\mathrm{KO}}$ mice that we examined, including the cortex, cerebellum, hypothalamus, hippocampus, and medulla oblongata (Fig. 1A). Immunoblot analysis demonstrated markedly reduced JNK1 protein

A

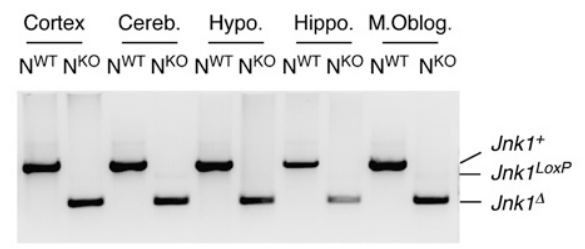

B

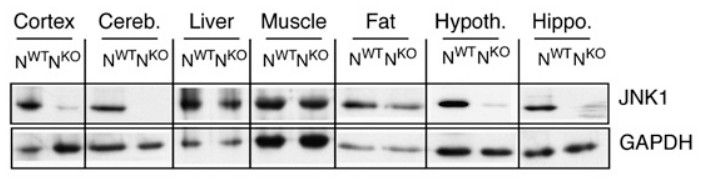

C

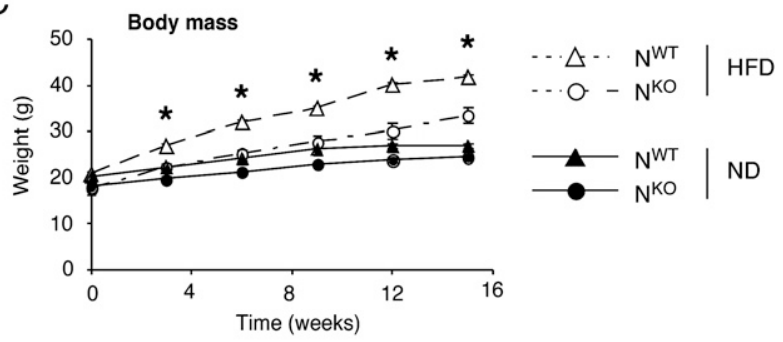

D

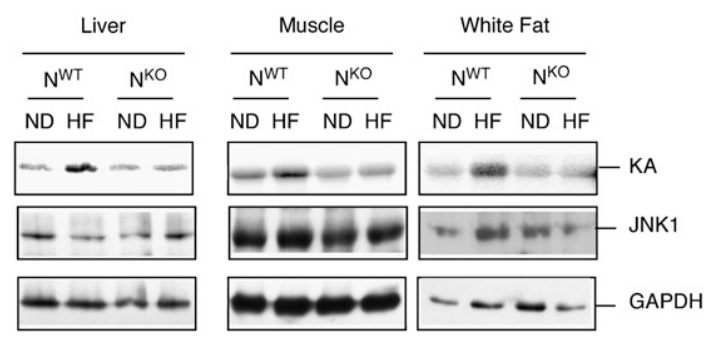

Figure 1. Creation of mice with nervous system-specific JNK1 deficiency. (A) Genotype analysis of genomic DNA isolated from the cortex, cerebellum (Cereb.), hippocampus (Hippo.), hypothalamus (Hypoth.), and medulla oblongata (M. Oblog.) of $\mathrm{NeS}_{-\mathrm{Cre} e^{+}} \mathrm{Ink} 1^{+/+}\left(\mathrm{N}^{\mathrm{WT}}\right)$ mice and Nes-Cre ${ }^{+}$Ink1 ${ }^{\text {LoxP/LoxP }}$ $\left(\mathrm{N}^{\mathrm{KO}}\right)$ mice was performed to detect the presence of $I n k 1^{+}$, $I n k 1^{\text {LoxP }}$, and $I n k 1^{\Delta}$ alleles. (B) Extracts prepared from the cortex, cerebellum, liver, muscle (quadriceps), fat (epididymal adipose tissue), hypothalamus, and hippocampus of $\mathrm{N}^{\mathrm{WT}}$ and $\mathrm{N}^{\mathrm{KO}}$ mice were examined using immunoblot analysis by probing with antibodies to JNK1 and GAPDH. $(C) \mathrm{N}^{\mathrm{WT}}$ and $\mathrm{N}^{\mathrm{KO}}$ male mice (8-10 wk old) were fed either a chow diet (ND) or a HFD (16 wk). The weight of the mice was measured (mean $\pm \mathrm{SD} n=10$ ). The HFD-induced weight gain of $\mathrm{N}^{\mathrm{WT}}$ was significantly greater than $\mathrm{N}^{\mathrm{KO}}$ mice $(P<0.05)$. $(D) \mathrm{N}^{\mathrm{WT}}$ and $\mathrm{N}^{\mathrm{KO}}$ mice were fed a chow diet (ND) or a HFD for 16 wk. JNK activity in the liver, quadriceps muscle, and epididymal adipose tissue was measured in a protein kinase assay (KA) assay using cJun and $\left[\gamma_{-}{ }^{32} \mathrm{P}\right] \mathrm{ATP}$ as substrates. The cell extracts used for the protein kinase assay were also examined by immunoblot analysis by probing with antibodies to JNK1 and GAPDH. in these subregions of the brain and normal amounts of JNK1 in liver, muscle, and adipose tissue (Fig. 1B). Control studies demonstrated that the $I n k 1$ gene was not deleted in $\beta$ cells of the Islets of Langerhans in $\mathrm{N}^{\mathrm{KO}}$ mice (Supplemental Fig. S1). These data indicate that $\mathrm{N}^{\mathrm{KO}}$ mice exhibit a tissue-specific defect in JNK1 expression. $\mathrm{N}^{\mathrm{KO}}$ mice therefore represent a model for the analysis of nervous systemspecific JNK1 deficiency.

\section{Nervous system INK1 is required for HFD-induced weight gain}

It has been established that HFD-fed $I n k 1^{-/-}$mice exhibit a severe defect in the development of diet-induced obesity (Hirosumi et al. 2002). However, selective JNK1 deficiency in adipose tissue, liver, muscle, or myeloid cells caused no defect in HFD-induced obesity (Sabio et al. 2008, 2009, 2010). These findings indicate that JNK1 function in another organ accounts for the effects of whole-body JNK1 deficiency to suppress HFD-induced weight gain. We therefore tested whether nervous systemspecific JNK1 deficiency might prevent HFD-induced weight gain. Comparison of chow-fed and HFD-fed $\mathrm{N}^{\mathrm{WT}}$ and $\mathrm{N}^{\mathrm{KO}}$ mice demonstrated that nervous system-specific JNK1 deficiency markedly reduced weight gain caused by a HFD (Fig. 1C).

Examination of organ mass at necropsy indicated a significant reduction in the weight of epididymal white fat, intrascapular brown fat, quadriceps muscle, and liver in HFD-fed $\mathrm{N}^{\mathrm{KO}}$ mice compared with $\mathrm{N}^{\mathrm{WT}}$ mice (Supplemental Fig. S2). In contrast, no significant difference in heart mass was detected between $\mathrm{N}^{\mathrm{KO}}$ and $\mathrm{N}^{\mathrm{WT}}$ mice (Supplemental Fig. S2). Measurement of lean and fat mass using ${ }^{1} \mathrm{H}-\mathrm{MRS}$ indicated that, while reduced fat accumulation by $\mathrm{N}^{\mathrm{KO}}$ mice was detected, the $\mathrm{N}^{\mathrm{KO}}$ mice also exhibited reduced lean mass compared with $\mathrm{N}^{\mathrm{WT}}$ mice (Fig. 2A). These data suggest that the defect in HFDinduced weight gain observed in $\mathrm{N}^{\mathrm{KO}}$ mice was due to a reduction in both fat and lean body mass.

The resistance to weight gain in HFD-fed $\mathrm{N}^{\mathrm{KO}}$ mice may account for the finding that HFD-induced JNK activation in adipose tissue, muscle, and liver of $\mathrm{N}^{\mathrm{WT}}$ mice was not detected in $\mathrm{N}^{\mathrm{KO}}$ mice (Fig. 1D).

\section{JNK1 deficiency increases insulin sensitivity}

The hyperglycemia and hyperinsulinemia caused by feeding a HFD to $\mathrm{N}^{\mathrm{WT}}$ mice was significantly reduced in HFDfed $\mathrm{N}^{\mathrm{KO}}$ mice (Fig. 3A). Similarly, the HFD-induced increase in the blood concentration of adipokines (leptin, resistin, and IL6) was markedly attenuated in HFD-fed $\mathrm{N}^{\mathrm{KO}}$ mice (Fig. 3A; Supplemental Fig. S3). Consistent with these observations, HFD-fed $\mathrm{N}^{\mathrm{KO}}$ mice were more glucosetolerant (Fig. 3B), more responsive in an insulin tolerance test (Fig. 3C), and exhibited increased glucose-induced insulin release (Fig. 3E) compared with HFD-fed $\mathrm{N}^{\mathrm{WT}}$ mice. These data indicate that HFD-fed $\mathrm{N}^{\mathrm{KO}}$ mice show increased insulin sensitivity and improved $\beta$-cell function compared with HFD-fed $\mathrm{N}^{\mathrm{WT}}$ mice. To confirm this conclusion, we conducted a hyperinsulinemic-euglycemic 
Sabio et al.

A
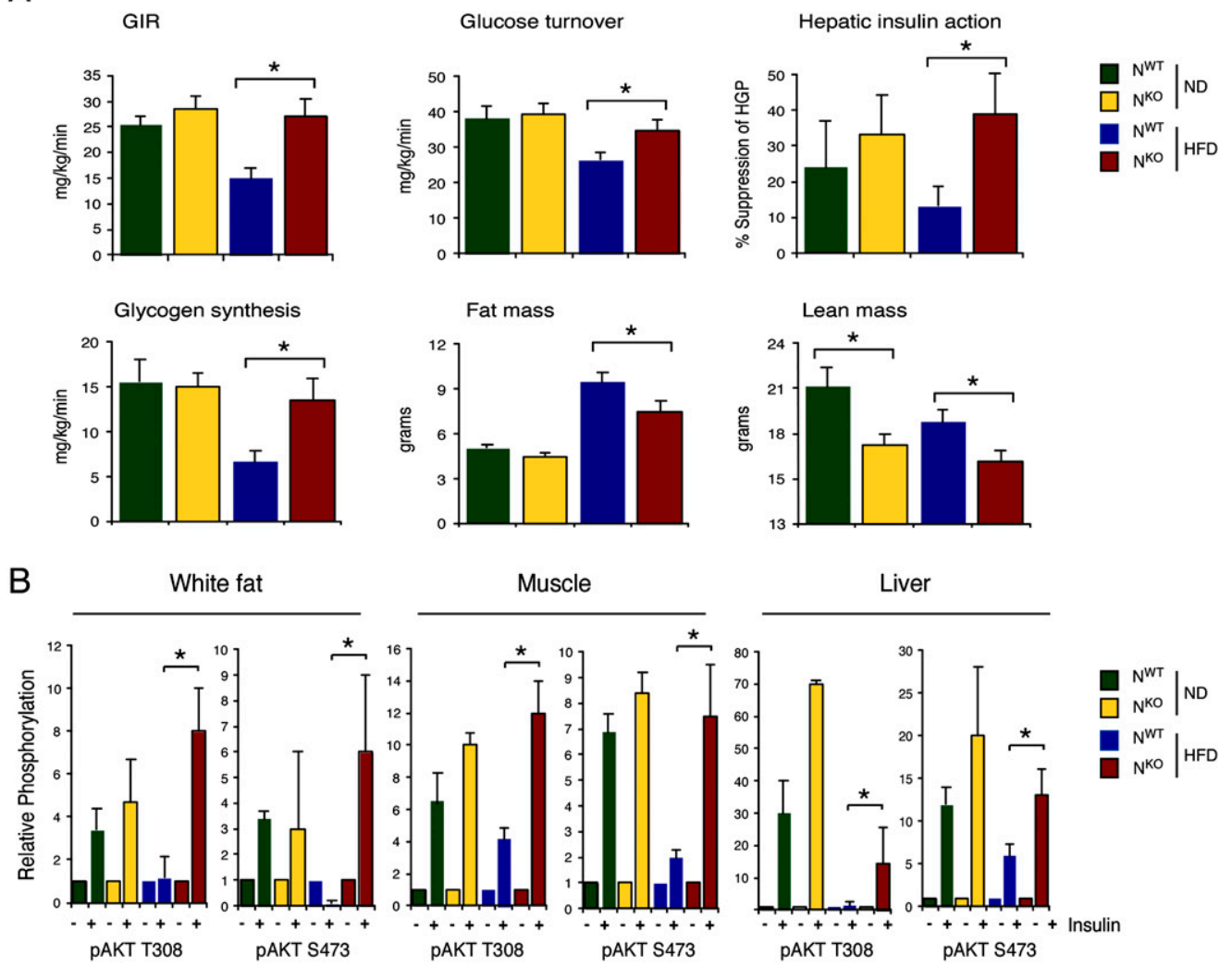

Figure 2. Effect of nervous system-specific JNK1 deficiency on insulin sensitivity. $(A)$ Insulin sensitivity was measured using a hyperinsulinemic-euglycemic clamp in conscious $\mathrm{N}^{\mathrm{KO}}$ and $\mathrm{N}^{\mathrm{WT}}$ mice. The steady-state glucose infusion rate (GIR), whole-body glucose turnover, hepatic insulin action, and whole-body glycogen plus lipid synthesis are presented. Fat and lean body mass were measured by ${ }^{1} \mathrm{H}$-MRS. The data presented are the mean \pm SE for six to approximately eight experiments. Statistically significant differences between $\mathrm{N}^{\mathrm{KO}}$ mice and $\mathrm{N}^{\mathrm{WT}}$ mice are indicated $\left(\left[{ }^{\star}\right] P<0.05\right)$. (B) Chow-fed $(\mathrm{ND})$ and HFD-fed $\mathrm{N}^{\mathrm{WT}}$ and $\mathrm{N}^{\mathrm{KO}}$ mice were treated by intraperitoneal injection of insulin (1.5 U/kg body mass). Extracts prepared from epididymal adipose tissue, quadriceps muscle, and liver at 15 min post-injection were examined by immunoblot analysis with antibodies to phospho-AKT (Thr-308 and Ser473) and AKT. Quantitation was performed using the Odyssey infrared imaging system (LI-COR Biosciences). The data presented are the mean $\pm \mathrm{SD}(n=3)$. Statistically significant differences between $\mathrm{N}^{\mathrm{KO}}$ mice and $\mathrm{N}^{\mathrm{WT}}$ mice are indicated $\left(\left[{ }^{\star}\right] P<0.05\right)$.

clamp study in conscious mice. This analysis demonstrated significant increases in steady-state glucose infusion rate, insulin-stimulated whole-body glucose turnover, glycogen plus lipid synthesis, and hepatic insulin action in HFD-fed $\mathrm{N}^{\mathrm{KO}}$ mice compared with HFD-fed $\mathrm{N}^{\mathrm{WT}}$ mice (Fig. 2A). These data confirmed that HFD-fed $\mathrm{N}^{\mathrm{KO}}$ mice are more insulin-sensitive than HFD-fed $\mathrm{N}^{\mathrm{WT}}$ mice.

To obtain biochemical evidence for insulin sensitivity, we examined insulin-stimulated AKT activation in adipose tissue, muscle, and liver of $\mathrm{N}^{\mathrm{KO}}$ and $\mathrm{N}^{\mathrm{WT}}$ mice (Fig. 2B). Insulin treatment increased AKT activation in chowfed $\mathrm{N}^{\mathrm{KO}}$ and $\mathrm{N}^{\mathrm{WT}}$ mice. Insulin-stimulated AKT activation was suppressed in adipose tissue, muscle, and liver of HFD-fed $\mathrm{N}^{\mathrm{WT}}$ mice, demonstrating insulin resistance in these organs (Fig. 2B). In contrast, studies of $\mathrm{N}^{\mathrm{KO}}$ mice demonstrated that the HFD did not inhibit insulinstimulated AKT activation in adipose tissue and muscle, and only partially suppressed AKT activation in liver (Fig. 2B). These data strongly support the conclusion that $\mathrm{N}^{\mathrm{KO}}$ mice exhibit protection against HFD-induced insulin resistance. This finding is consistent with the observa- tion that $\mathrm{N}^{\mathrm{KO}}$ mice did not gain weight in response to feeding a HFD (Fig. 1C).

\section{INK1 deficiency reduces food intake}

Metabolic cage analysis demonstrated that HFD-fed $\mathrm{N}^{\mathrm{KO}}$ mice consumed slightly less food than HFD-fed $\mathrm{N}^{\mathrm{WT}}$ mice (Fig. 4). This decrease in food intake may contribute to the failure of HFD-fed $\mathrm{N}^{\mathrm{KO}}$ mice to gain weight. We did not detect changes in the expression of hypothalamic neuropeptides that regulate satiety (agouti-related protein [AgRP], cocaine and amphetamine-regulated transcript $[\mathrm{CART}]$, promelanin-concentrating hormone $[\mathrm{PMCH}]$, and pro-opiomelanocortin [POMC]) that might account for decreased feeding behavior by HFD-fed $\mathrm{N}^{\mathrm{KO}}$ mice (Fig. 5A). However, increased leptin signaling might contribute to the observed reduction in food intake. The adipokine leptin acts on multiple subsets of neurons in the CNS to suppress feeding behavior (Myers et al. 2009). The blood leptin concentration was reduced in HFD-fed $\mathrm{N}^{\mathrm{KO}}$ mice compared with HFD-fed $\mathrm{N}^{\mathrm{WT}}$ mice (Fig. 3A). Nevertheless, 
A
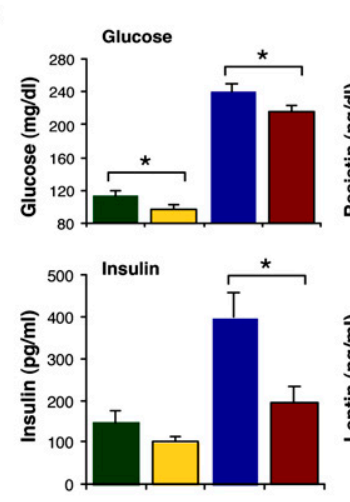

C

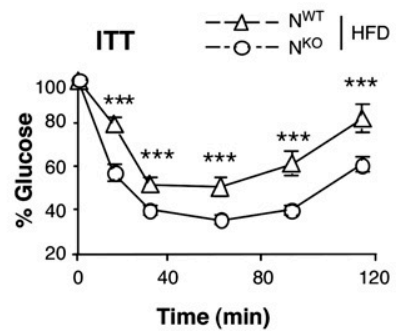

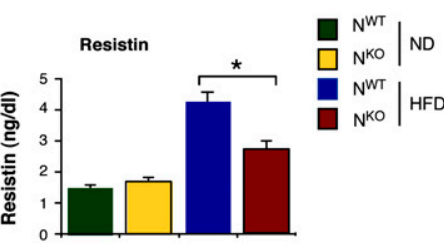

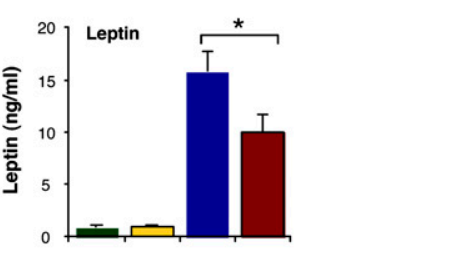

D

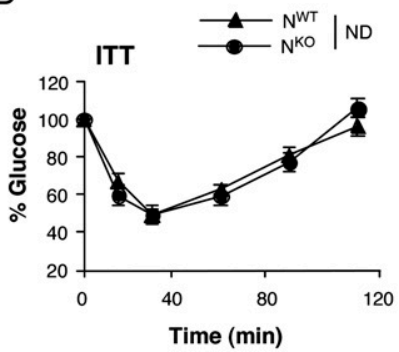

B
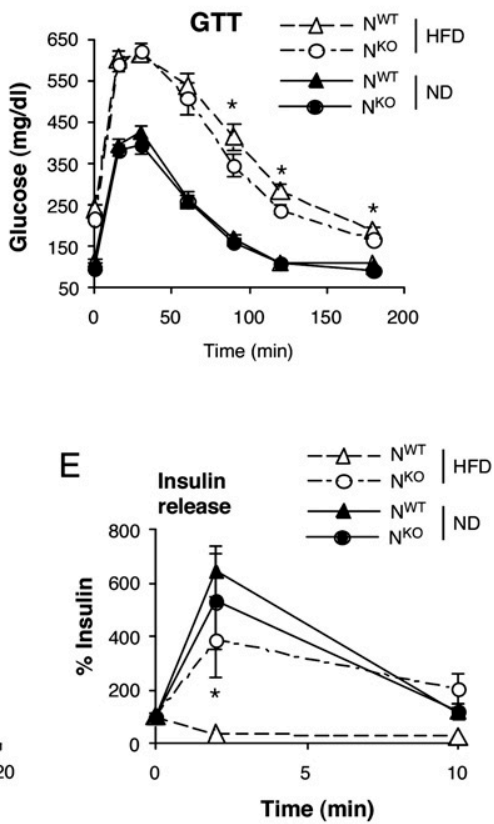

Figure 3. JNK1 deficiency in the nervous system partially protects mice against the metabolic effects of feeding a HFD. (A) Blood glucose concentration in chow-fed (ND) and HFD-fed $\mathrm{N}^{\mathrm{WT}}$ and $\mathrm{N}^{\mathrm{KO}}$ mice fasted overnight. The blood concentration of insulin, resistin, and leptin in mice fasted overnight is also presented. The data represent the mean \pm SD $(n=10)$. Statistically significant differences between $\mathrm{N}^{\mathrm{KO}}$ and $\mathrm{N}^{\mathrm{WT}}$ are indicated ([*] $\left.P<0.05\right)$. (B) Glucose tolerance tests $(\mathrm{GTT})$ on chow-fed (ND) and HFD-fed $\mathrm{N}^{\mathrm{WT}}$ and $\mathrm{N}^{\mathrm{KO}}$ mice were performed by measurement of blood glucose concentration in animals following intraperitoneal injection of glucose $(1 \mathrm{~g} / \mathrm{kg})$. The data presented represent the mean $\pm \mathrm{SD}(n=10 \sim 15)$. Statistically significant differences between $\mathrm{N}^{\mathrm{KO}}$ and $\mathrm{N}^{\mathrm{WT}}$ are indicated $\left(\left[{ }^{\star}\right] P<\right.$ 0.05). $(C, D)$ Insulin tolerance tests (ITT) on $\mathrm{N}^{\mathrm{WT}}$ and $\mathrm{N}^{\mathrm{KO}}$ mice fed either a chow diet (ND) or a HFD were performed by intraperitoneal injection of insulin (1.5 U/kg body mass). The concentration of blood glucose was measured (mean $\pm \mathrm{SD} ; n=10)$. Statistically significant differences between $\mathrm{N}^{\mathrm{KO}}$ and $\mathrm{N}^{\mathrm{WT}}$ are indicated $\left.\left({ }^{\star \star \star}\right] P<0.001\right)$. (E) Glucose-induced insulin release. The effect of administration of glucose $(2 \mathrm{~g} / \mathrm{kg}$ body mass) by intraperitoneal injection on blood insulin concentration was examined (mean \pm SD; $n=13 \sim 15)$. Statistically significant differences between $\mathrm{N}^{\mathrm{WT}}$ and $\mathrm{N}^{\mathrm{KO}}$ mice are indicated $\left(\left[{ }^{\star}\right] P<0.05\right)$.

increased hypothalamic leptin signaling in HFD-fed $\mathrm{N}^{\mathrm{KO}}$ mice could mediate increased leptin sensitivity. It has been established that leptin receptor expression is regulated by blood leptin concentration and obesity (Townsend et al. 2008). Indeed, leptin receptor expression is downregulated in HFD-fed mice (Townsend et al. 2008). However, feeding a HFD did not down-regulate leptin receptor expression in the hypothalamus of HFD-fed $\mathrm{N}^{\mathrm{KO}}$ mice (Fig. 5A). This failure of leptin receptor down-regulation may contribute to decreased feeding by HFD-fed $\mathrm{N}^{\mathrm{KO}}$ mice compared with HFD-fed $\mathrm{N}^{\mathrm{WT}}$ mice.

\section{INK1 deficiency increases energy expenditure}

We performed metabolic cage analysis of $\mathrm{N}^{\mathrm{KO}}$ and $\mathrm{N}^{\mathrm{WT}}$ mice to determine the effects of nervous system-specific JNK1 deficiency on energy balance (Fig. 4). No difference in the respiratory exchange quotient $\left(\left[\mathrm{V}_{\mathrm{CO} 2}\right] /\left[\mathrm{V}_{\mathrm{O} 2}\right]\right)$ between $\mathrm{N}^{\mathrm{KO}}$ and $\mathrm{N}^{\mathrm{WT}}$ mice was detected. However, the HFD-fed $\mathrm{N}^{\mathrm{KO}}$ mice exhibited a large increase in physical activity and energy expenditure compared with HFD-fed $\mathrm{N}^{\mathrm{WT}}$ mice (Fig. 4). This effect of JNK1 deficiency to cause increased energy expenditure and physical activity is likely to be a major determinant of JNK1-regulated obe- sity, and may largely account for the failure of HFD-fed $\mathrm{N}^{\mathrm{KO}}$ mice to gain weight.

\section{INK1 deficiency engages the hypothalamic-pituitary- thyroid axis}

We found that $\mathrm{N}^{\mathrm{KO}}$ mice exhibited elevated body temperature (Fig. 6A) that was associated with a reduction in lipid accumulation by brown fat and liver in HFD-fed $\mathrm{N}^{\mathrm{KO}}$ mice compared with HFD-fed $\mathrm{N}^{\mathrm{WT}}$ mice (Fig. 6B). Gene expression analysis demonstrated that $\mathrm{N}^{\mathrm{KO}}$ mice expressed larger amounts of mRNA derived from thyroid hormone target genes (Supplemental Fig. S5; Obregon 2008). These data indicate that the thyroid hormone pathway is activated in $\mathrm{N}^{\mathrm{KO}}$ mice. Indeed, increased levels of $\mathrm{T} 4$ and $\mathrm{T} 3$ were detected in the blood of $\mathrm{N}^{\mathrm{KO}}$ mice compared with $\mathrm{N}^{\mathrm{WT}}$ mice (Fig. 6C). This change was associated with increased expression of thyrotropin-releasing hormone (Trh) mRNA in the hypothalamus of chow-fed $\mathrm{N}^{\mathrm{KO}}$ mice (Fig. 6C), increased expression of thyroid-stimulating hormone (Tsh) mRNA in the pituitary gland (Fig. 5B), and increased TSH protein in the blood of HFD-fed $\mathrm{N}^{\mathrm{KO}}$ mice (Fig. 6C). TSH and TRH expression are subject to acute negative feedback regulation by thyroid hormone (Björkman and Ekholm 

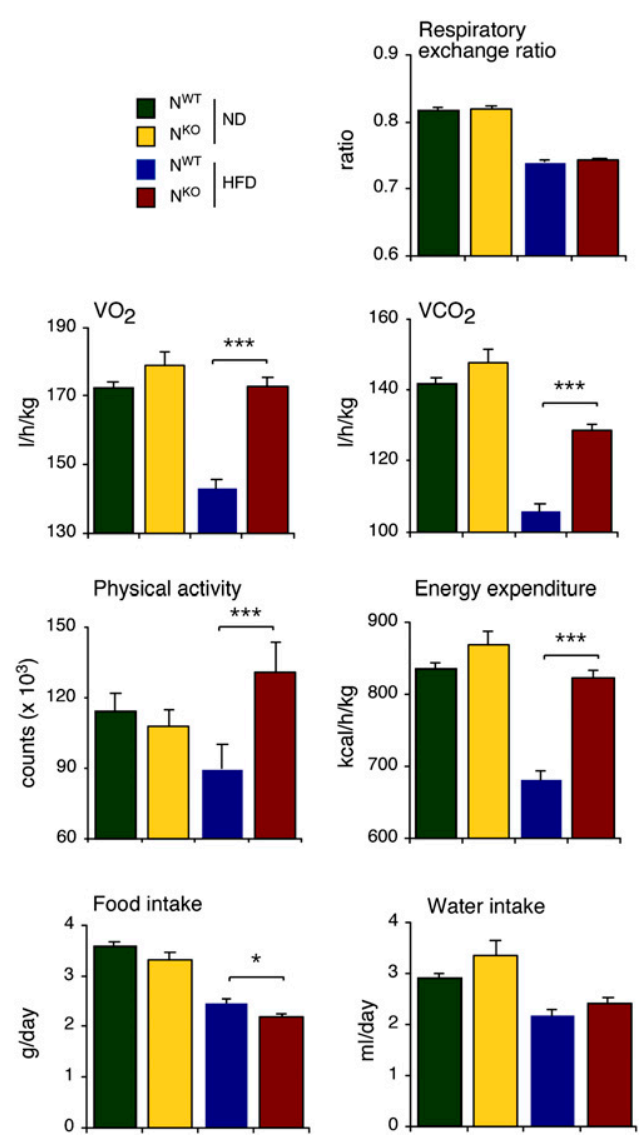

Figure 4. Comparison of energy balance of $\mathrm{N}^{\mathrm{WT}}$ and $\mathrm{N}^{\mathrm{KO}}$ mice using metabolic cages. Mice were examined during a 3-d period to measure the food and water consumption, gas exchange $\left(\mathrm{V}_{\mathrm{O} 2}\right.$ and $\left.\mathrm{V}_{\mathrm{CO} 2}\right)$, respiratory exchange quotient $\left[\mathrm{V}_{\mathrm{CO} 2}\right] /\left[\mathrm{V}_{\mathrm{O} 2}\right]$, energy expenditure, and physical activity (mean $\pm \mathrm{SE}, n=6)$. Statistically significant differences between $\mathrm{N}^{\mathrm{KO}}$ mice and $\mathrm{N}^{\mathrm{WT}}$ mice are indicated $\left.\left(\left[{ }^{\star}\right] P<0.05 ;\left[^{\star \star}\right] P<0.01 ;{ }^{{ }^{\star \star \star}}{ }^{\star}\right] P<0.001\right)$.

2000). The presence of high levels of T4 and T3 in the blood of $\mathrm{N}^{\mathrm{KO}}$ mice under conditions where TSH and TRH expression are elevated suggests that brain JNK1 deficiency disrupts the normal negative feedback regulation of the hypothalamic-pituitary axis.

The effect of JNK1 deficiency on TSH expression suggests that brain-specific JNK1 knockout mice may have altered pituitary function. Indeed, HFD-fed $\mathrm{N}^{\mathrm{KO}}$ mice were found to have decreased amounts of adrenocorticotropic hormone (ACTH) and increased amounts of growth hormone (GH) in the blood compared with HFD-fed $\mathrm{N}^{\mathrm{WT}}$ mice (Supplemental Fig. S4). These data support the conclusion that JNK1 is required for normal pituitary function.

\section{The hypothalamic-pituitary-thyroid axis contributes to metabolic regulation by INK1}

To test whether increased thyroid hormone signaling was causally related to the defect in HFD-induced weight gain in $\mathrm{N}^{\mathrm{KO}}$ mice, we examined the effect of treatment of mice with propylthiouracil (PTU), a drug that inhibits thyroperoxidase and prevents $\mathrm{T} 4$ production by the thyroid gland (Björkman and Ekholm 2000). We treated $\mathrm{N}^{\mathrm{KO}}$ and $\mathrm{N}^{\mathrm{WT}}$ mice with PTU in the drinking water and examined the effect of feeding a chow diet or a HFD. Analysis of intrascapular brown fat demonstrated that PTU treatment suppressed the increased expression of thyroid hormone-responsive genes in $\mathrm{N}^{\mathrm{KO}}$ mice (Supplemental Fig. S5). These data demonstrate that PTU treatment represents an effective model to study the role of thyroid hormone signaling in $\mathrm{N}^{\mathrm{KO}}$ and $\mathrm{N}^{\mathrm{WT}}$ mice. We found that the PTU-treated $\mathrm{N}^{\mathrm{KO}}$ and $\mathrm{N}^{\mathrm{WT}}$ mice showed similar increases in body weight when fed a HFD (Fig. 7A; Supplemental Fig. S6). No significant differences in glucose, insulin, and adipokine (leptin and resistin) concentrations in the blood or body temperature between PTU-treated $\mathrm{N}^{\mathrm{KO}}$ and $\mathrm{N}^{\mathrm{WT}}$ mice were detected (Fig. 7B). Similarly, no significant differences between PTU-treated $\mathrm{N}^{\mathrm{KO}}$ and $\mathrm{N}^{\mathrm{WT}}$ mice were detected in glucose and insulin tolerance tests (Fig. 7C). Together, these data demonstrate that inhibition of thyroid hormone by PTU treatment markedly suppressed the metabolic phenotypes of $\mathrm{N}^{\mathrm{KO}}$ mice. This analysis supports the conclusion that increased thyroid hormone contributes to the metabolic phenotype of $\mathrm{N}^{\mathrm{KO}}$ mice.

To test the contribution of thyroid hormone to the phenotype of whole-body JNK1 knockout mice, we examined the effect of PTU treatment on $I n k 1^{-1-}$ mice. We found that PTU treatment significantly suppressed the effect of whole-body JNK1 deficiency on HFDinduced weight gain, hyperglycemia, glucose intolerance, insulin sensitivity, and glucose-induced insulin release (Supplemental Figs. S7, S8). However, the PTU treatment caused greater suppression of the metabolic phenotype of $\mathrm{N}^{\mathrm{KO}}$ mice than $I n k 1^{-/-}$mice, consistent with metabolic roles of JNK1 in both neuronal and nonneuronal tissues.

\section{Discussion}

The mechanism of obesity-induced insulin resistance, metabolic syndrome, and type 2 diabetes may involve the JNK1 signaling pathway. Thus, mouse studies have demonstrated that treatment with JNK inhibitors can reduce hyperglycemia and improve insulin sensitivity (Bennett et al. 2003; Kaneto et al. 2004; Stebbins et al. 2008). Moreover, $I n k 1^{-1-}$ mice are protected against the development of HFD-induced obesity and insulin resistance (Hirosumi et al. 2002). Analysis of tissue-specific JNK1 knockout mice demonstrates that JNK1 deficiency in adipose tissue, muscle, liver, or myeloid cells does not prevent HFD-induced weight gain (Sabio et al. 2008, 2009, 2010). Nevertheless, adipose tissue-specific $\mathrm{N}^{\mathrm{KO}}$ mice do exhibit defects in HFD-induced insulin resistance in adipose tissue and liver (Sabio et al. 2008). Moreover, muscle-specific $\mathrm{N}^{\mathrm{KO}}$ mice are protected against HFDinduced muscle insulin resistance (Sabio et al. 2010). These observations demonstrate that JNK1 can regulate insulin resistance independently of the effects of JNK1 on HFD-induced weight gain. In addition, this analysis established that JNK1-regulated insulin resistance involves more than one mechanism, including JNK1-regulated expression of inflammatory cytokines (Sabio et al. 2008), 

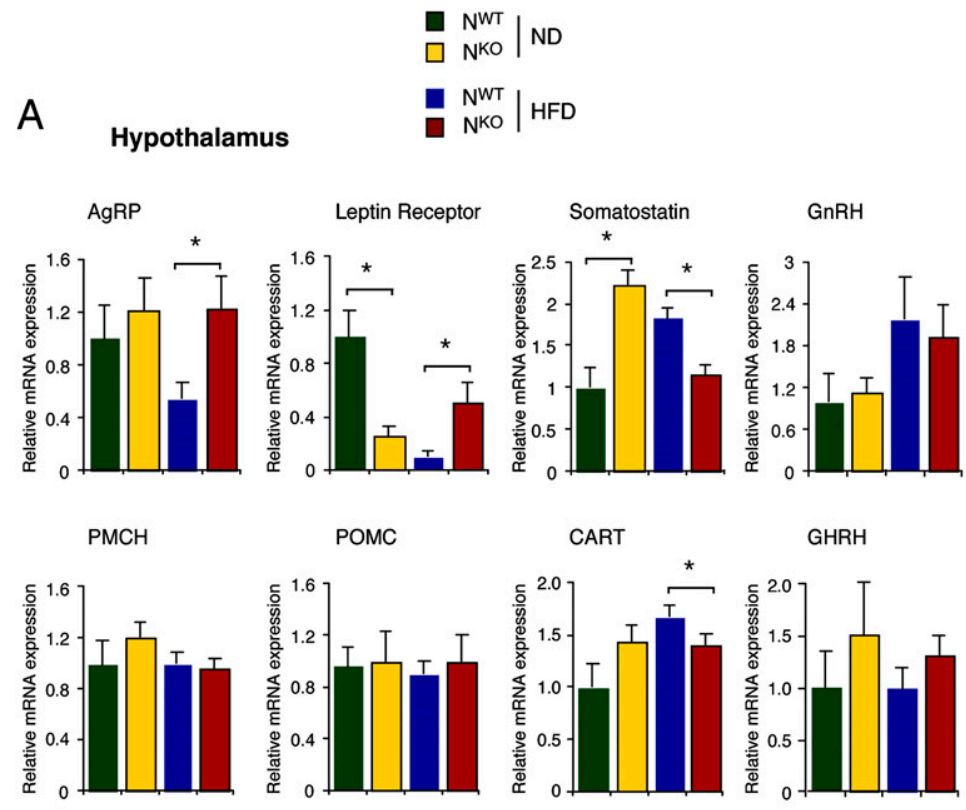

B

Pituitary gland
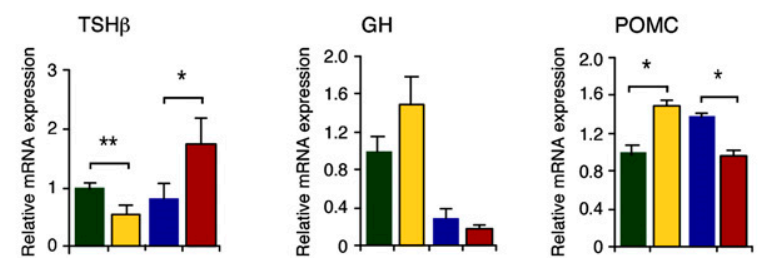

Figure 5. Gene expression in the hypothalamus and pituitary gland of $\mathrm{N}^{\mathrm{WT}}$ and $\mathrm{N}^{\mathrm{KO}}$ mice. $(A) \mathrm{N}^{\mathrm{WT}}$ and $\mathrm{N}^{\mathrm{KO}}$ mice were fed a chow diet (ND) or a HFD (16 wk) and then fasted overnight. The expression of AgRP, leptin receptor, somatostatin, gonadotrophin-releasing hormone $(\mathrm{GnRH}), \mathrm{PMCH}, \mathrm{POMC}, \mathrm{CART}$, and GH-releasing hormone (GHRH) mRNA in the hypothalamus was measured by quantitative RT-PCR. The data were normalized to the expression of Gapdh mRNA in each sample. The data are presented as the mean $\pm \operatorname{SD}(n=6)$. Statistically significant differences between $\mathrm{N}^{\mathrm{WT}}$ and $\mathrm{N}^{\mathrm{KO}}$ mice are indicated ([ $\left.\left.{ }^{*}\right] P<0.05\right) .(B)$ The expression of TSH $\beta, \mathrm{GH}$, and POMC mRNA in the pituitary gland was measured by quantitative RT-PCR. The data were normalized to the expression of Gapdh mRNA in each sample. The data are presented as the mean $\pm \operatorname{SD}(n=6)$. Statistically significant differences between $\mathrm{N}^{\mathrm{WT}}$ and $\mathrm{N}^{\mathrm{KO}}$ mice are indicated $\left.\left(\left[{ }^{\star}\right] P<0.05 ;{ }^{\star \star}\right] P<0.01\right)$.
JNK1-regulated expression of lipoprotein lipase (Sabio et al. 2010), and JNK1-mediated negative regulatory phosphorylation of the insulin receptor adapter protein IRS1 (Aguirre et al. 2000; Hirosumi et al. 2002; Lee et al. 2003; Sabio et al. 2008, 2010).

JNK1 deficiency in the nervous system is sufficient to protect mice against weight gain caused by feeding a HFD. The weight gain of $\mathrm{N}^{\mathrm{WT}}$ mice is mediated, in part, by reduced physical activity and energy expenditure. In contrast, feeding a HFD to mice with JNK1 deficiency in the nervous system ( $\mathrm{N}^{\mathrm{KO}}$ mice) does not cause decreased physical activity and energy expenditure. This maintenance of physical activity and energy expenditure in HFD-fed $\mathrm{N}^{\mathrm{KO}}$ mice contributes to the failure of these mice to gain weight when fed a HFD.

The increased energy expenditure in $\mathrm{N}^{\mathrm{KO}}$ mice is mediated, in part, by activation of the hypothalamicpituitary-thyroid axis. This conclusion is based on several lines of evidence, including increased body temperature, increased expression of thyroid hormone-induced genes, and increased amounts of T4 and T3 in the blood of $\mathrm{N}^{\mathrm{KO}}$ mice compared with $\mathrm{N}^{\mathrm{WT}}$ mice. Moreover, pharmacological inhibition of thyroid hormone production abolished the metabolic phenotypes of $\mathrm{N}^{\mathrm{KO}}$ mice, including marked suppression of HFD-induced weight gain. These data identify the hypothalamic-pituitary-thyroid axis as an important target of the metabolic actions of JNK1.
The thyroid hormone pathway is negatively regulated by JNK1. The increased amount of T4 and T3 in the blood of $\mathrm{N}^{\mathrm{KO}}$ mice compared with $\mathrm{N}^{\mathrm{WT}}$ mice correlates with increased expression of hypothalamic TRH and pituitary gland TSH. These changes in TRH and TSH expression were unexpected because thyroid hormone exerts powerful negative feedback control of TRH and TSH expression (Björkman and Ekholm 2000). The association of increased T4 and T3 in the blood with increased expression of $\mathrm{TRH}$ and $\mathrm{TSH}$ in $\mathrm{N}^{\mathrm{KO}}$ mice indicates that JNK1 deficiency in the brain disrupts the normal negative feedback control of the hypothalamic-pituitary-thyroid axis. An important goal for future studies will be to determine the molecular mechanism of JNK1 regulation of the hypothalamic-pituitary-thyroid axis.

In conclusion, this study demonstrates that JNK1 deficiency in the nervous system is sufficient to account for the role of JNK1 in the regulation of HFD-induced weight gain. This knowledge has important implications for the design of novel therapeutic interventions in the treatment of diet-induced obesity.

\section{Materials and methods}

\section{Mice}

We previously described $I n k 1^{-l-}$ mice (Dong et al. 1998) and Ink $1^{\text {LoxP/LoxP }}$ mice (Das et al. 2007). Nes-Cre mice (Tronche et al. 
A

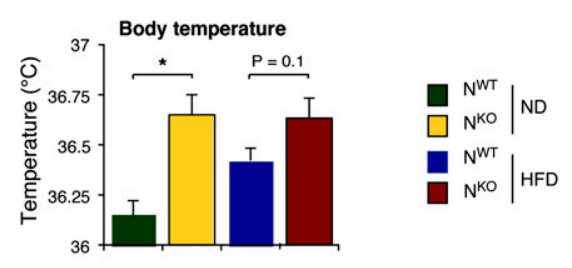

B

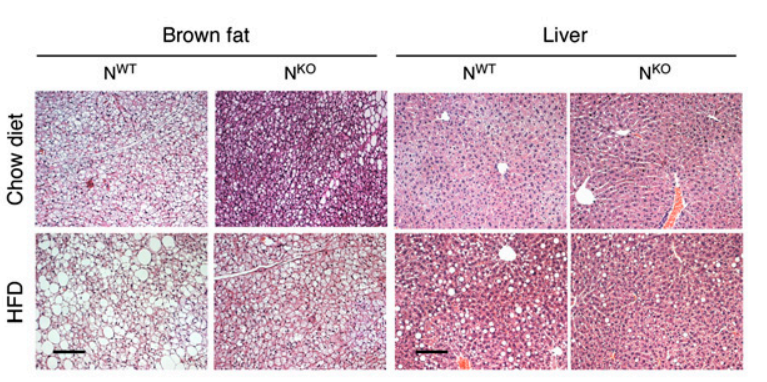

C
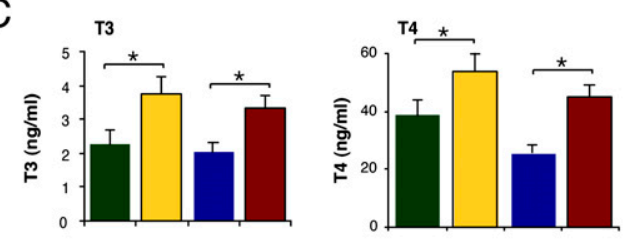

$\square \mathrm{N}^{\mathrm{K} O} \mid \mathrm{ND}$
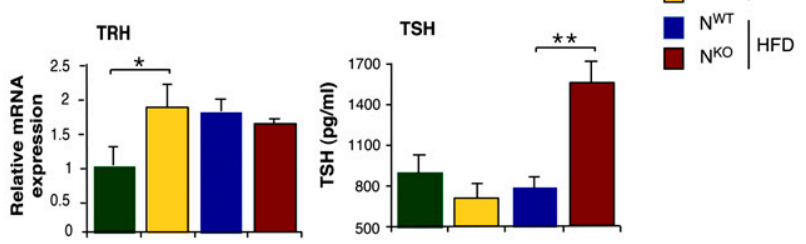

Figure 6. Activation of the hypothalamic-pituitary-thyroid hormone axis in $\mathrm{N}^{\mathrm{KO}}$ mice. $(A)$ The body temperature of chow-fed (ND) and HFD-fed $\mathrm{N}^{\mathrm{KO}}$ and $\mathrm{N}^{\mathrm{WT}}$ mice are presented (mean $\pm \mathrm{SD} ; n=8$ ). Statistically significant differences between $\mathrm{N}^{\mathrm{KO}}$ and $\mathrm{N}^{\mathrm{WT}}$ mice are indicated $\left(\left[{ }^{\star}\right] P<0.05\right)$. (B) Sections prepared from intrascapular brown fat and liver of chow-fed (ND) and HFD-fed $\mathrm{N}^{\mathrm{KO}}$ and $\mathrm{N}^{\mathrm{WT}}$ mice were stained with hematoxylin and eosin. Bar, $100 \mu \mathrm{m}$. $(C)$ The concentration of T3, T4, and TSH in the blood of chow-fed (ND) and HFD-fed $\mathrm{N}^{\mathrm{KO}}$ and $\mathrm{N}^{\mathrm{WT}}$ mice was measured by ELISA (mean $\pm \mathrm{SD}, n=$ 10). The amount of Trh mRNA in the hypothalamus was measured by quantitative RT-PCR analysis and was normalized to the amount of Gapdh mRNA measured in each sample (mean \pm $\mathrm{SD} ; n=6 \sim 7)$. Statistically significant differences between $\mathrm{N}^{\mathrm{KO}}$ and $\mathrm{N}^{\mathrm{WT}}$ mice are indicated $\left(\left[{ }^{\star}\right] P<0.05 ;\left[{ }^{\star \star}\right] P<0.01\right)$.

1999) were obtained from The Jackson Laboratories, and Rip$C r e^{E S R}$ mice (Dor et al. 2004) were obtained from D. Melton (Harvard University). The mice were backcrossed to the C57BL/ 6J strain (The Jackson Laboratories) and were housed in facilities accredited by the American Association for Laboratory Animal Care (AALAC). The mice were genotyped by PCR analysis of genomic DNA (Das et al. 2007). All studies were performed using male mice (8-24 wk old). The mice were treated with PTU in the drinking water (cherry-flavored Kool-Aid supplemented without or with $1.2 \mathrm{mM}$ PTU [Sigma]). Body temperature was measured using a Microtherma 2 Type " $\mathrm{T}$ " Thermometer (Braintree Scientific, Inc.). Rip-Cre $e^{E S R}$ mice were treated with $1 \mathrm{mg}$ of 4-hydroxytamoxifen (Sigma) by intraperitoneal injection once each day for five consecutive days. The animal studies were approved by the Institutional Animal Care and Use Committees of the University of Massachusetts Medical School and the Pennsylvania State University College of Medicine.

\section{RNA analysis}

The expression of mRNA was examined by quantitative PCR analysis using a 7500 Fast Real-Time PCR machine. TaqMan assays were used to quantitate Acc $\beta$ (Mm01204683_m1), Agrp (Mm00475829_g1), Cart (Mm00489086_m1), Ghrh (Mm01250745_ m1), Gnrh (Mm01315605_m1), Gh (Mm00433590-g1), Glut4 (Mm00436615-m1), Ldh $\beta$ (Mm00493146_m1), Leptin receptor (Mm00434759_m1), Pck1 (Mm00440636_m1), Pmch (Mm242886_ g1), Pomc (Mm00599949_m), Somatostatin (Mm 00436671_m1), Spot14 (Mm01273967_m1), Trh (Mm01963590_s1), Tsh $\beta$ (Mm00437190_m1), and Ucp1 (Mm01244861-m1). The relative mRNA expression was normalized by measurement of the amount of Gapdh mRNA (\#4352339E) in each sample using TaqMan assays (Applied Biosystems).

\section{Isolation of pancreatic islets}

Murine pancreatic islets were isolated using methods described previously (Mangada et al. 2009).

\section{Immunoblot analysis}

Tissue extracts were prepared using Triton lysis buffer $(20 \mathrm{mM}$ Tris at $\mathrm{pH} 7.4,1 \%$ Triton X-100, 10\% glycerol, $137 \mathrm{mM} \mathrm{NaCl}$, 2 mM EDTA, $25 \mathrm{mM} \beta$-glycerophosphate, $1 \mathrm{mM}$ sodium orthovanadate, $1 \mathrm{mM}$ phenylmethylsulfonyl fluoride, $10 \mu \mathrm{g} / \mathrm{mL}$ of aprotinin and leupeptin). Extracts (20-50 $\mu$ g of protein) were examined by protein immunoblot analysis by probing with antibodies to AKT, phospho-Thr ${ }^{308}$ AKT, and phospho-Ser ${ }^{473}$ AKT (Cell Signaling); and JNK1 and GAPDH (Santa Cruz Biotechnologies). Immunocomplexes were detected by enhanced chemiluminescence (NEN). Quantitation of immunoblots was performed using the Odyssey infrared imaging system (LI-COR Biosciences).

\section{Measurement of blood glucose, adipokine, cytokine, and insulin concentration}

Blood glucose was measured with an Ascensia Breeze 2 glucometer (Bayer). Adipokines, cytokines, and insulin in plasma were measured by ELISA using a Luminex 200 machine (Millipore).

\section{Glucose and insulin tolerance tests}

The mice were fed a standard chow diet or a HFD (Iso Pro 3000, Purina; and F3282, Bioserve, Inc.) for 16 wk. Glucose and insulin tolerance tests were performed using methods described previously (Mora et al. 2005).

\section{Protein kinase assays}

JNK activity was measured using an in vitro protein kinase assay with the substrates cJun and $\left[\gamma^{-}{ }^{32} \mathrm{P}\right] \mathrm{ATP}$ as substrates (Whitmarsh and Davis 2001).

\section{Hyperinsulinemic-euglycemic clamp studies}

The clamp studies were performed at the University of Massachusetts Mouse Phenotyping Center. Briefly, mice were fed a HFD diet (55\% fat by calories; Harlan Teklad) or chow diet 
A

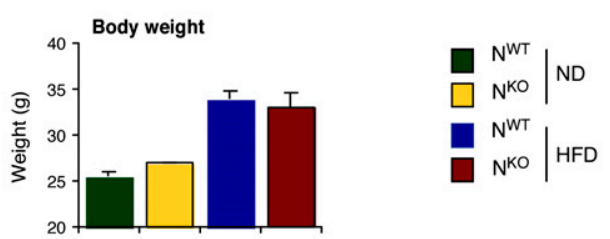

B
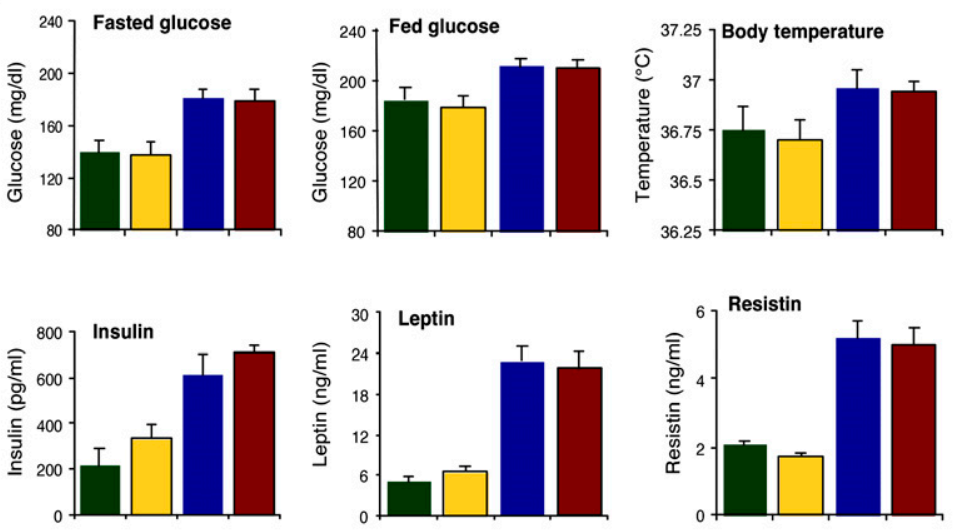

C
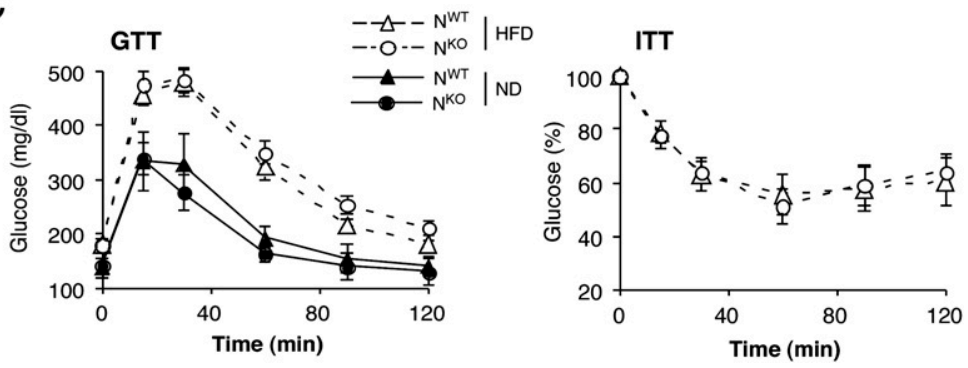

Figure 7. Disruption of thyroid hormone signaling prevents the effects of nervous system-specific JNK1 deficiency on HFD-induced weight gain. $(A) \mathrm{N}^{\mathrm{KO}}$ and $\mathrm{N}^{\mathrm{WT}}$ mice were treated with PTU in the drinking water. The mice were divided into chow-fed (ND) and HFD-fed groups after $2 \mathrm{wk}$, and then maintained for an additional $10 \mathrm{wk}$. The body weight of the mice is presented. No statistically significant differences between $\mathrm{N}^{\mathrm{KO}}$ and $\mathrm{N}^{\mathrm{WT}}$ mice were detected $(P>0.05)$. (B) Chow-fed (ND) and HFD-fed $\mathrm{N}^{\mathrm{KO}}$ and $\mathrm{N}^{\mathrm{WT}}$ mice were examined after $12 \mathrm{wk}$ of treatment with PTU. The blood glucose concentration in fed and overnight fasted mice, body temperature, and the blood hormone (insulin, leptin, and resistin) concentrations are presented. No significant differences between $\mathrm{N}^{\mathrm{KO}}$ and $\mathrm{N}^{\mathrm{WT}}$ mice were detected $(P>0.05) .(C)$ Glucose tolerance tests (GTT) on PTU-treated chowfed (ND) and HFD-fed $\mathrm{N}^{\mathrm{KO}}$ and $\mathrm{N}^{\mathrm{WT}}$ mice are presented. No significant differences between $\mathrm{N}^{\mathrm{KO}}$ and $\mathrm{N}^{\mathrm{WT}}$ mice were detected $(P>0.05)$. Insulin tolerance tests (ITT) on PTU-treated HFD-fed $\mathrm{N}^{\mathrm{KO}}$ and $\mathrm{N}^{\mathrm{WT}}$ mice are presented. No significant differences between $\mathrm{N}^{\mathrm{KO}}$ and $\mathrm{N}^{\mathrm{WT}}$ mice were detected $(P>0.05)$. for $3 \mathrm{wk}$, and whole-body fat and lean mass were noninvasively measured using ${ }^{1}$ H-MRS (Echo Medical Systems). Following an overnight fast, a 2-h hyperinsulinemic-euglycemic clamp was conducted in conscious mice with a primed and continuous infusion of human insulin $(150 \mathrm{mU} / \mathrm{kg}$ body weight priming followed by $2.5 \mathrm{mU} / \mathrm{kg} / \mathrm{min}$; Humulin; Eli Lilly), and $20 \%$ glucose was infused at variable rates to maintain euglycemia (Kim et al. 2004). Whole-body glucose turnover was assessed with a continuous infusion of $\left[3-{ }^{3} \mathrm{H}\right]$ glucose, and 2-deoxy-D$\left[1-{ }^{14} \mathrm{C}\right]$ glucose (PerkinElmer) was administered as a bolus (10 $\mu \mathrm{Ci})$ at $75 \mathrm{~min}$ after the start of the clamps to measure insulinstimulated glucose uptake in individual organs. At the end of the clamps, mice were anesthetized, and tissues were taken for biochemical analysis (Kim et al. 2004).

\section{Metabolic cages}

Mice were housed under controlled temperature and lighting with free access to food and water. The food/water intake, energy expenditure, respiratory exchange ratio, and physical activity were performed (3 d) using metabolic cages (TSE Systems).

\section{Analysis of tissue sections}

Histology was performed using tissue fixed in $10 \%$ formalin for $24 \mathrm{~h}$, dehydrated, and embedded in paraffin. Sections $(7 \mu \mathrm{m})$ were cut and stained using hematoxylin and eosin (American Master Tech Scientific).

\section{Statistical analysis}

Differences between groups were examined for statistical significance using the Student's test or analysis of variance (ANOVA) with the Fisher's test.

\section{Acknowledgments}

We thank D. Greiner for assistance with the isolation of pancreatic islets, J. Leonard for expert advice, D. Melton for providing Rip-Cre ${ }^{E S R}$ mice, M. Das for providing $\operatorname{Ink} 1^{\operatorname{LoxP}}$ mice, V. Benoit and J-H. Liu for technical assistance, and K. Gemme for administrative assistance. These studies were supported by grants from the National Institutes of Health (CA65861 to R.J.D., and DK80756 to J.K.K.) and the American Diabetes Association (7-07-RA-80 to J.K.K.). This study was supported by the University of Massachusetts Mouse Phenotyping Center (National Institute of Diabetes and Digestive and Kidney Diseases, Diabetes and Endocrinology Research Center, grant DK52530) and the Penn State Diabetes and Obesity Mouse Phenotyping Center (Pennsylvania State Department of Health Tobacco Settlement Award to J.K.K.). R.J.D. is an Investigator of the Howard Hughes Medical Institute. 


\section{References}

Aguirre V, Uchida T, Yenush L, Davis R, White MF. 2000. The c-Jun $\mathrm{NH}_{2}$-terminal kinase promotes insulin resistance during association with insulin receptor substrate-1 and phosphorylation of Ser(307). J Biol Chem 275: 9047-9054.

Bennett BL, Satoh Y, Lewis AJ. 2003. JNK: A new therapeutic target for diabetes. Curr Opin Pharmacol 3: 420-425.

Björkman U, Ekholm R. 2000. Biochemistry of thyroid hormone formation and secretion. In The thyroid gland (ed. Greer MA), pp. 83-125. Raven Press, New York.

Das M, Jiang F, Sluss HK, Zhang C, Shokat KM, Flavell RA, Davis RJ. 2007. Suppression of p53-dependent senescence by the JNK signal transduction pathway. Proc Natl Acad Sci 104: 15759-15764.

Dong C, Yang DD, Wysk M, Whitmarsh AJ, Davis RJ, Flavell RA. 1998. Defective T cell differentiation in the absence of Jnk1. Science 282: 2092-2095.

Dor Y, Brown J, Martinez OI, Melton DA. 2004. Adult pancreatic $\beta$-cells are formed by self-duplication rather than stem-cell differentiation. Nature 429: 41-46.

Hirosumi J, Tuncman G, Chang L, Gorgun CZ, Uysal KT, Maeda K, Karin M, Hotamisligil GS. 2002. A central role for JNK in obesity and insulin resistance. Nature 420: 333-336.

Kahn SE, Hull RL, Utzschneider KM. 2006. Mechanisms linking obesity to insulin resistance and type 2 diabetes. Nature 444: 840-846.

Kaneto H, Nakatani Y, Miyatsuka T, Kawamori D, Matsuoka TA, Matsuhisa M, Kajimoto Y, Ichijo H, Yamasaki Y, Hori M. 2004. Possible novel therapy for diabetes with cell-permeable JNK-inhibitory peptide. Nat Med 10: 1128-1132.

Kim HJ, Higashimori T, Park SY, Choi H, Dong J, Kim YJ, Noh HL, Cho YR, Cline G, Kim YB, et al. 2004. Differential effects of interleukin- 6 and -10 on skeletal muscle and liver insulin action in vivo. Diabetes 53: 1060-1067.

Lee YH, Giraud J, Davis RJ, White MF. 2003. c-Jun N-terminal kinase (JNK) mediates feedback inhibition of the insulin signaling cascade. J Biol Chem 278: 2896-2902.

Lenard NR, Berthoud HR. 2008. Central and peripheral regulation of food intake and physical activity: Pathways and genes. Obesity (Silver Spring) 16: S11-S22. doi: 10.1038/ oby.2008.511.

Mangada J, Pearson T, Brehm MA, Wicker LS, Peterson LB, Shultz LD, Serreze DV, Rossini AA, Greiner DL. 2009. Idd loci synergize to prolong islet allograft survival induced by costimulation blockade in NOD mice. Diabetes 58: 165-173.

Mora A, Sakamoto K, McManus EJ, Alessi DR. 2005. Role of the PDK1-PKB-GSK3 pathway in regulating glycogen synthase and glucose uptake in the heart. FEBS Lett 579: 36323638.

Myers MG Jr, Munzberg H, Leinninger GM, Leshan RL. 2009. The geometry of leptin action in the brain: More complicated than a simple ARC. Cell Metab 9: 117-123.

Obregon MJ. 2008. Thyroid hormone and adipocyte differentiation. Thyroid 18: 185-195.

Sabio G, Das M, Mora A, Zhang Z, Jun JY, Ko HJ, Barrett T, Kim JK, Davis RJ. 2008. A stress signaling pathway in adipose tissue regulates hepatic insulin resistance. Science 322: 1539-1543.

Sabio G, Cavanagh-Kyros J, Ko HJ, Jung DY, Gray S, Jun JY, Barrett T, Mora A, Kim JK, Davis RJ. 2009. Prevention of steatosis by hepatic JNK1. Cell Metab 10: 491-498.

Sabio G, Cavanagh-Kyros J, Ko HJ, Jung DY, Gray S, Jun JY, Barrett T, Kim JK, Davis RJ. 2010. Role of muscle JNK1 in obesity-induced insulin resistance. Mol Cell Biol. 30: 106-115.
Stebbins JL, De SK, Machleidt T, Becattini B, Vazquez J, Kuntzen C, Chen LH, Cellitti JF, Riel-Mehan M, Emdadi A, et al. 2008. Identification of a new JNK inhibitor targeting the JNK-JIP interaction site. Proc Natl Acad Sci 105: 1680916813.

Townsend KL, Lorenzi MM, Widmaier EP. 2008. High-fat dietinduced changes in body mass and hypothalamic gene expression in wild-type and leptin-deficient mice. Endocrine 33: $176-188$.

Tronche F, Kellendonk C, Kretz O, Gass P, Anlag K, Orban PC, Bock R, Klein R, Schutz G. 1999. Disruption of the glucocorticoid receptor gene in the nervous system results in reduced anxiety. Nat Genet 23: 99-103.

Weston CR, Davis RJ. 2007. The JNK signal transduction pathway. Curr Opin Cell Biol 19: 142-149.

Whitmarsh AJ, Davis RJ. 2001. Analyzing JNK and p38 mitogenactivated protein kinase activity. Methods Enzymol 332: 319-336. 


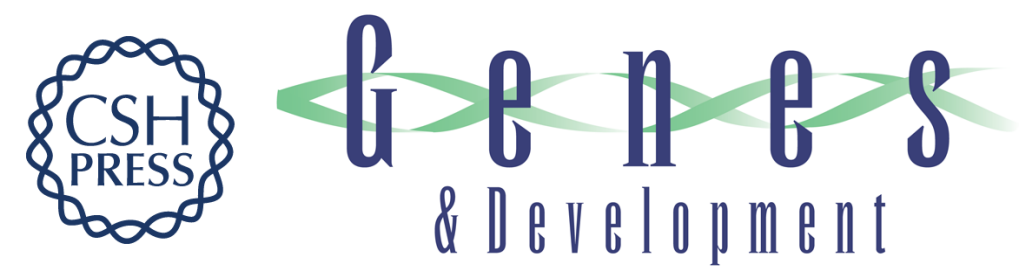

\section{Role of the hypothalamic-pituitary-thyroid axis in metabolic regulation by JNK1}

Guadalupe Sabio, Julie Cavanagh-Kyros, Tamera Barrett, et al.

Genes Dev. 2010, 24: originally published online January 15, 2010

Access the most recent version at doi:10.1101/gad.1878510

\section{Supplemental http://genesdev.cshlp.org/content/suppl/2009/12/30/gad.1878510.DC1 \\ Material}

References This article cites 23 articles, 9 of which can be accessed free at:

http://genesdev.cshlp.org/content/24/3/256.full.html\#ref-list-1

\section{License}

Email Alerting

Receive free email alerts when new articles cite this article - sign up in the box at the top

Service

right corner of the article or click here.

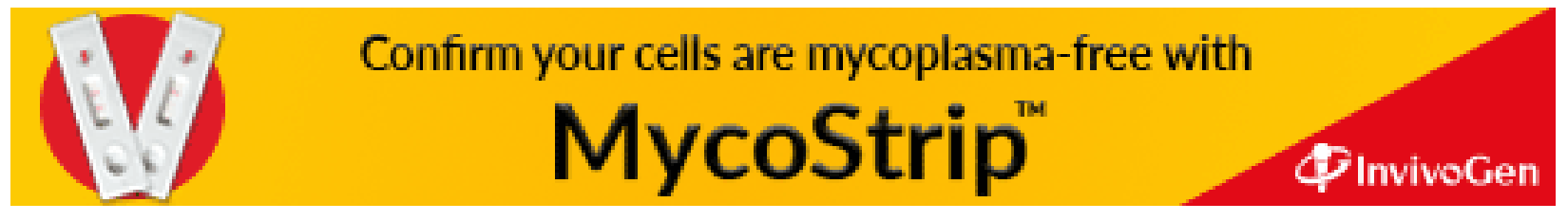

